\section{New Intergeneric Somatic Hybrids Combining Amblycarpa Mandarin with Six Trifoliate/Trifoliate Hybrid Selections for Lime Rootstock Improvement}

\author{
Victor Medina-Urrutia and Karla Fabiola Lopez Madera \\ INIFAP-Campo Experimental Tecoman, KM35 Carretera Colima-Manzanillo \\ Tecoman, Colima CP28100, Mexico \\ Patricia Serrano, G. Ananthakrishnan, and Jude W. Grosser ${ }^{\mathbf{1}}$ \\ Department of Horticulture, University of Florida, Citrus Research and \\ Education Center, Institute of Food and Agricultural Sciences, Lake Alfred, \\ FL 33850

\section{Wenwu Guo \\ National Key Laboratory of Crop Genetic Improvement, Huazhong Agricultural University, Wuhan, Hubei 430070, P.R. China}

Additional index words. disease resistance, protoplast fusion, tetraploid, tree size control, tissue culture, molecular markers

\begin{abstract}
No presently available rootstock combines all the available rootstock attributes necessary for efficient long-term citriculture (production and harvesting) of Mexican limes and other commercially important scions. In the present study, somatic hybridization techniques were used to combine the widely adapted Amblycarpa mandarin (also known as Nasnaran mandarin) with six different trifoliate/trifoliate hybrid selections: Benton, Carrizo, and C-35 citranges; Flying Dragon and Rubidoux trifoliate oranges; and a somatic hybrid of sour orange + Flying Dragon. The ultimate goal of this research is to generate polyploid somatic hybrids that express the complementary horticultural and disease resistance attributes of the corresponding parents, and have direct potential as improved tree-size controlling rootstocks. Somatic hybrids from all six parental combinations were confirmed by a combination of leaf morphology, flow cytometry, and randomly amplified polymorphic DNA (RAPD) (for nuclear hybridity) and cleaved amplified polymorphic sequence (CAPS) analyses (for mtDNA and cpDNA). This is the first report of citrus somatic hybridization using Amblycarpa mandarin. Unexpected hexaploid somatic hybrid plants were recovered from the fusion of Amblycarpa mandarin + C-35 citrange. Hexaploid hybrids should be very dwarfing and may have potential for producing potted ornamental citrus. Resulting somatic hybrid plants from all six combinations have been propagated by tissue culture and/or rooted cuttings and are being prepared for commercial field evaluation for their potential as improved rootstocks for Mexican lime and other important scions.
\end{abstract}

Mexicanlime [Citrusaurantifolia(Christm) Swingle] is an important citrus crop in Mexico, with more than 90,000 ha grown in the Central and South Pacific Coast of Mexico (MedinaUrrutia and Robles-Gonzalez, 2000a). Phytophthora nicotianae Breda de Haan (syn.

Received for publication 28 Apr. 2003. Accepted for publication 3 Dec. 2003. This research was supported by the Florida Agricultural Experimen Station, and approved for publication as Journal Series No. R-09405. The authors thank the Fundacion Produce Colima, Fundacion Produce Michoacan, and CONACYT-Simorelos No. 980301008 (Mexico), and the Florida Citrus Production Research Advisory Council for grants that provided partial support of this research. The authors also thank Drs. Salvador Guzman-Gonzalez and Alfonso Pescador Rubio of the Univ. of Colima, Mexico, for their valuable advice on the project.

${ }^{1}$ To whom reprint requests should be addressed. E-mail: jwg@crec.ifas.ufl.edu
P. Parasitica Dastur) caused an annual death rate of $3 \%$ to $5 \%$ of lime trees propagated by seed during the 1970s. Therefore, seedling lime trees were slowly replaced by budded trees on sour orange $(C$. aurantium L.) and Troyer and Carrizo citrange [Citrus sinensis (L.) Osbeck X Poncirus trifoliata (L.) Raf.] rootstocks. Trees on citranges were poorly adapted to the calcareous soils in this region (Medina-Urrutia, 1996). Field experiments were established to compare 13 rootstocks on four different soil types for Mexican lime trees during the 1980s. Trees on Alemow (Citrus macrophylla Wester), Volkamer lemon(Citrus volkameriana Pasq \& Ten.), and Amblycarpa mandarin (Citrus amblycarpa Ochse) had excellent horticultural performance, and these rootstocks decreased the impact of biotic and soil problems (Medina-Urrutia, 1996; Valdez-Verduzco and Medina-Urrutia, 1981).
However, the trees grew to an unacceptably large size. Poncirus trifoliata and its hybrid rootstocks showed potential to reduce tree size, and a few have shown better adaptation to calcareous soil conditions (Medina-Urrutia and Robles-Gonzalez, 2000b).

Trifoliate orange (Poncirus trifoliata) is a very important species for rootstock breeding as it is very cold hardy and highly resistant to root rot (Phytophthora sp.), citrus tristeza virus (CTV), and the citrus nematode (Castle et al., 1993; Ferguson and Garnsey, 1993). Generally, trifoliate orange grows well in acidic soils, and it moderately dwarfs most scion cultivars (Castle et al., 1993). However, it is susceptible to citrus exocortis viroid (CEV) (Ferguson and Garnsey, 1993), and not well adapted to high soil pH (Castle, 1987). More recently, citranges (Citrus sinensis $\times$ P. trifoliata) and citrumelos $(C$. paradisi Macf. $\times P$. trifoliata $)$ have become the dominant rootstocks in Florida and elsewhere (Bronson et al., 2002). The most widely planted trifoliate-derived hybrid rootstocks are Carrizo and Troyer citranges, and Swingle citrumelo (Bronson et al., 2002; Castle, 1987). Other citranges (Benton, C-32, C-35, and Morton) and citrumelos (C.paradisi $\times$ P. trifoliata; selections from the F-80 series in Florida) are recommended for trials of smaller acreages (Castle et al., 1993). Carrizo citrange is highly susceptible to citrus blight (Castle, 1987), and blight is an increasingly important problem with other popular trifoliate hybrid rootstocks. Mandarin-type rootstocks are very important because they are resistant to CEV, xyloporosis, and CTV (Castle, 1987; Castle et al., 1993; Ferguson and Garnsey, 1993). Mexican lime on Amblycarpa mandarin performed very well on soils of different textures and depths, and in elevated soil $\mathrm{pH}$ in the Colima area of Mexico (Medina-Urrutia, 1996). Persian lime (C. latifolia Tan.) trees on Amblycarpa mandarin planted in a Rockdale soil were performing better than on several other rootstocks, including Cleopatra and Sun Chu Sha mandarins in a 3-year-old trial that was subsequently destroyed during the cankereradication program in south Florida (W.S. Castle, unpublished data). Amblycarpa is also more tolerant of boron than other commercial rootstocks, including Cleopatra mandarin ( $\mathrm{J}$. Forner, personal communication). Amblycarpa mandarin appears to be one of the most widely adapted mandarins available for rootstock improvement. The number of mandarin types and trifoliate hybrid rootstocks obtained by sexual hybridization has been limited. Recently, some new hybrids were released in Florida and Spain (Bowman, 2000; Forner et al., 2000), and some others will be available in the near future in South Africa and Argentina (Foguet, 2000; Miller et al., 2000). The mandarin species involved in these crosses with trifoliate types were Citrus reticulata Blanco (Cleopatra and Changsha), Citrus sunki Hort ex. Tan., and 'Minneola' tangelo ( $C$. paradisi $\times$ C. reticulata).

Somatic hybridization is a successful technique being utilized in citrus scion and rootstock improvement programs. So far, more than 200 new somatic hybrids have been produced 
in the world by cell fusion involving intergeneric and interspecific parental combinations (Grosser et al., 2000; Guo and Deng, 2001). Among them, 20 intergeneric somatic hybrids combining trifoliate orange $[P$. trifoliata $(\mathrm{L})$. Raf.] with citrus species have been obtained (Grosser et al., 2000; Ohgawara et al., 1994), and these include Cleopatra mandarin with Flying Dragon trifoliate orange (Grosser et al., 1992) and Argentine trifoliate orange (Grosser et al., 1994); Changsha mandarin with trifoliate orange 50-7 and Benton citrange (Grosser and Chandler, 2000); willow leaf mandarin ( $C$. reticulata $\mathrm{Blanco})$ with trifoliate orange (O1litraut et al., 1996); Page tangelo (C. paradisi $\times C$. reticulata) with trifoliate orange (Guo et al., 2000); and Red tangerine (C. reticulata Blanco) with trifoliate orange (Guo et al., 2002). The development of somatic hybrids that incorporate complementary traits of trifoliate orange and mandarin-type rootstocks continues to be an objective of rootstock improvement programs (Grosser etal., 2000). Somatic hybrid citrus rootstocks are showing good potential to reduce tree size, as needed, for more efficient high-density plantings (Grosser, 2003), and somatic hybrid rootstocks that combine trifoliate orange or citranges with mandarins are producing small- to medium-size trees with good yields of high quality fruit. For example, sweet orange trees on the following somatic hybrid rootstocks produced trees with average canopy volumes much smaller than standard trees on diploid Carrizo citrange (data presented as percent canopy volume of trees on Carrizo): Cleopatra + Carrizo (60\%); Cleopatra + Argentine trifoliate orange (58\%); Changsha mandarin + Benton citrange $(38 \%)$; Cleopatra + Flying Dragon (35\%) (J.W. Grosser, unpublished data). The goal of the present research is to combine Amblycarpa mandarin with various trifoliate/trifoliate hybrid selections in efforts to produce more widely adapted and disease-resistant rootstocks with potential to control tree size. To the best of our knowledge, no previous sexual or somatic hybrids containing Amblycarpa mandarin have been reported.

Many recent studies have been adapting emerging biotechniques to verify somatic hybridity (see Grosser et al., 2000) and organelle inheritance in citrus somatic hybrids and cybrids (Cabasson etal., 2001; Guo et al., 2002; Moreira et al., 2000a, 2000b). A combination of morphology, flow cytometry, and RAPD and CAPS analyses were used to characterize and verify the resulting somatic hybrids in the present study. Detailed molecular analyses regarding nuclear and organelle genome contributions from parents in new somatic hybrids should facilitate future applications of somatic hybridization and cybridization techniques in citrus variety improvement.

\section{Materials and Methods}

\section{Protoplast Isolation, Fusion, and Culture}

Plant material. An embryogenic suspension culture of $C$. amblycarpa mandarin from the collection of embryogenic cultures maintained at the Citrus Research and Education Center, Univ. of Florida, was used. Suspension cultures were established from embryogenic callus initiated from undeveloped ovules and cultured according to Grosser and Gmitter (1990). Callus-derived protoplasts were obtained from an Amblycarpa mandarin suspension culture (days 4 to 12) that was continuously maintained in $\mathrm{H}+\mathrm{H}$ liquid medium on a 2-week subculture cycle (Grosser and Gmitter, 1990).

Putative typical nucellar seedlings of Benton, Carrizo, and C-35 citranges, Flying Dragon and Rubidoux trifoliate oranges (Poncirus trifoliata), and the tetraploid sour orange + Flying Dragon somatic hybrid were maintained in small pots in a low-light (via double shadecloth) greenhouse. Tender, fully expanded leaves from these plants were used to obtain leaf-derived protoplasts.

Protoplast isolation and fusion. Protoplast isolation from the Amblycarpa suspension culture was achieved by plating $\approx 1 \mathrm{~g}$ of cell suspension into a $60 \times 15 \mathrm{~mm}$ petri dish. The liquid suspension medium was carefully drained off using a Pasteur pipet and replaced with $2.5 \mathrm{~mL} 0.7 \mathrm{~m} \mathrm{BH} 3$ protoplast culture medium. One and one-half milliliters of enzyme solution containing $1 \%$ macerase, $0.2 \%$ pectolyase, and $1 \%$ cellulase (Grosser and Gmitter, 1990) was added drop by drop, and plates were sealed with Nescofilm. Selected leaves from the greenhouse plants were decontaminated by immersion in $1 \mathrm{~N}$ $\mathrm{HCl}$ for $5 \mathrm{~s}$, followed by immersion in $20 \%$ commercial bleach for $15 \mathrm{~min}$, and rinsed in sterile, distilled water for $10 \mathrm{~min}$. Leaves were feather-cut with a sharp scalpel and put in a $100-\mathrm{mL}$ Kitasato flask containing $3 \mathrm{~mL}$ of the same enzyme solution described above and $8.0 \mathrm{~mL}$ of $0.6 \mathrm{~m} \mathrm{BH}$. Flasks containing leaves were placed under vacuum for $25 \mathrm{~min}$ at $50 \mathrm{KPa}$ to facilitate enzyme infiltration, and then incubated in darkness for 10 to $12 \mathrm{~h}$ at $30{ }^{\circ} \mathrm{C}$ on a rotary shaker at $50 \mathrm{rpm}$. Following incubation, protoplasts from both sources were purified by passage through a $45-\mu \mathrm{m}$ stainless steel screen mesh, followed by centrifugation on a sucrose-mannitol gradient as described by Grosser and Gmitter (1990).

Suspension culture-derived protoplasts of Amblycarpa mandarin were always fused with leaf-derived protoplasts of the respective trifoliate/trifoliate hybrid parent. Equal volumes of purified protoplasts from each parental source were mixed and fused using the PEG (40\% polyethylene glycol) technique according to Grosser and Gmitter (1990). After the final wash, protoplasts were cultured in a $1: 1(\mathrm{v}: \mathrm{v})$ mixture of $0.6 \mathrm{MBH} 3$ and $0.6 \mathrm{MEME}$ protoplast culture media (Grosser and Gmitter, 1990), and petri dishes were sealed with Nescofilm and maintained in plastic boxes.

Protoplast culture and plant regeneration. Fusion cultures were incubated at $28^{\circ} \mathrm{C}$ in low light for 21 to $28 \mathrm{~d}$, and then supplemented with fresh medium containing reduced osmoticum by adding 10 to 12 drops of $1: 1: 1$ (v:v:v) mixture of $0.6 \mathrm{~m} \mathrm{BH} 3: 0.6 \mathrm{~m} \mathrm{EME} \mathrm{:} 0.15 \mathrm{~m} \mathrm{EME}$ media (Grosser and Gmitter, 1990). Following another incubation period of $2-4$ weeks, $\approx 3 \mathrm{~mL}$ of a 1:2 (v:v) mixture of 0.6 м BH3 medium and $0.15 \mathrm{M}$ EME liquid medium was added to each plate. Plates were then gently swirled and the entire contents poured over agar-solified EME medium in $20 \times 100 \mathrm{~mm}$ petri dishes. Embryogenic callus colonies grew rapidly on these plates, and somatic embryo formation occurred spontaneously within 6 to 10 weeks. Somatic embryos were enlarged on 1500 medium, and germination was attempted on $(\mathrm{B}+)$ embryo germination medium (Grosser and Gmitter, 1990). Abnormal embryos not producing shoots were transferred to DBA3 adventitious shoot bud-induction medium (Deng et al., 1992). Germinated shoots from either source were transferred to RMAN medium (Grosser and Gmitter, 1990) in Magenta boxes for root induction. Rooted plantlets were transferred to 38-welled plastic containers containing a commercial potting mix and maintained under high humidity in a $50 \%$ shaded greenhouse until acclimated.

\section{Verification of Somatic Hybrids}

Morphological evaluation. Leaves from regenerated plants and parental types were examined for morphological differences in leaf shape, thickness, size, color intensity, and petiole wing size. The dominant trifoliate leaf type was the most useful marker for somatic hybrid and cybrid identification since unfused leaf protoplasts are not capable of direct plant regeneration.

Ploidy determination. Leaf samples of regenerated plants were analyzed by flow cytometry (Ollitrault et al., 1994) to determine the ploidy level (diploid, tetraploid, or hexaploid) using a Partec ploidy analyzer. Leaf material was chopped with a sharp razor blade in $1 \mathrm{~mL}$ of Partec nuclear extraction buffer. After 30 to $40 \mathrm{~s}$ incubation, samples were filtered through a 50- $\mu \mathrm{m}$ nylon filter. To stain the nuclei, 1.5 to $2 \mathrm{~mL}$ of Partec staining solution was added to each test sample. Leaf samples of Hirado Buntan pummelo (Citrus grandis L. Osbeck) were included as a diploid control, and a previously produced tetraploid somatic hybrid was used as a tetraploid control. The relative fluorescence intensity of thousands of nuclei per sample was analyzed at a wavelength of $488 \mathrm{~nm}$. The ploidy level of each regenerated plant was determined by peak position relative to that of the control plants.

$R A P D$ analysis. Total DNA was extracted from leaves of putative tetraploid somatic hybrids and their related parents for RAPD analysis, using a GenElute plant genomic DNA kit by Sigma. DNA samples were amplified using a DNA Thermal Cycler 480 (Perkin Elmer, Torrance, Calif.). The following random primers were utilized: A-08, A-19, C-11, C-64(Operon Technologies, Alameda, Calif.). Adequate polymorphisms for verification of nuclear hybridization via complementary banding parents were obtained with primers C-11 and C-64; therefore, only results using these primers are presented. Sequences of C-11 and C-64 were AGGTACGCCCGA and CCAGATCCGAAT, respectively. Am- 
plification of DNA was performed under the following reaction conditions: one cycle of 2 min at $94^{\circ} \mathrm{C}$; followed by 34 cycles for $1 \mathrm{~min}$ of denaturing at $94{ }^{\circ} \mathrm{C}, 1 \mathrm{~min}$ of annealing at $42{ }^{\circ} \mathrm{C}$, and a 2 -min extension at $72{ }^{\circ} \mathrm{C}$; a final extension for $10 \mathrm{~min}$ at $72{ }^{\circ} \mathrm{C}$. Amplification products were separated on a $1 \%$ agarose gel containing $1 \mathrm{X}$ TAE buffer and $0.5 \mu \mathrm{g} \cdot \mathrm{mL}^{-1}$ ethidium bromide for $2.5 \mathrm{~h}$ at $2.5 \mathrm{~V} \cdot \mathrm{cm}^{-1}$, and visualized under ultraviolet (UV) light.

CAPS analysis of cytoplasmic genomes. For mtDNA and cpDNA analysis, DNA digestions were performed using the following protocol: the three mitochondria-specific and four chloroplast-specific primer pairs utilized for amplification were: Nad1ExonB-Nad1ExonC, Nad4Exon1-Nad4Exon2, 18S rRNA-5S rRNA for mt-DNA analysis; and rbcL-rbcL, rbcLPSAI, TrnH-TrnK, and TrnD-TrnK forcp-DNA analysis, respectively (for primer sequences, refer to Cheng et al., 2003) (Operon Technologies). Polymerase chain reaction (PCR) conditions were as follows: one initial denaturing cycle at $94{ }^{\circ} \mathrm{C}$ for $3 \mathrm{~min}, 32$ cycles of $1 \mathrm{~min}$ at $94{ }^{\circ} \mathrm{C}$ for denaturation, $40 \mathrm{~s}$ of annealing at $55^{\circ} \mathrm{C}$, a 2 -min extension at $72{ }^{\circ} \mathrm{C}$, and a final extension step of $10 \mathrm{~min}$ at $72^{\circ} \mathrm{C}$. Aliquots of 5-8 $\mu$ L of the PCR products were each digested with $4 \mathrm{U}$ of restriction endonuclease TaqI at 65 ${ }^{\circ} \mathrm{C}$ for $3 \mathrm{~h}$. DNA was analyzed by electrophoresis of the digested DNA sample on a $3.0 \%$ Metaphor agarose (BMA, Rockland, Maine) with $1 \mathrm{X} \mathrm{TAE}$ and $5 \mu \mathrm{g} \cdot \mathrm{mL}^{-1}$ ethidium bromide for $2.5 \mathrm{~h}$ at $2.5 \mathrm{~V} \cdot \mathrm{cm}^{-1}$, and photographing the samples under UV light.

\section{Result and Discussion}

Protoplast isolation and plant regeneration. The Amblycarpa suspension culture routinely generated high yields of high-quality protoplasts, up to 10 -fold that of other citrus suspension cultures. Purified protoplasts were very uniform in size and very sticky, tending to aggregate. Preliminary experiments (data not shown) testing various times of incubation in the enzyme solution $(8,16,24$, or 32 h) produced similar yields, indicating that cell wall degradation occurred rapidly. Previous work with mandarin embryogenic callus and suspension cultures showed that mandarins generally perform less optimally than sweet orange cultures regarding protoplast isolation, culture, and subsequent plant regeneration. Experiments with Citrus reticulata cv. Red tangerine showed that embryogenic callus was susceptible to browning when subcultured on solid and in liquid medium, and grew slowly, making somatic hybridization studies difficult (Guo et al., 2002). We have had similar experiences with Satsuma and Cleopatra cultures (J.W. Grosser, unpublished data). In this work, production of protoplasts was efficient at any time during the subculture period, and isolated protoplasts were cultured easily, making Amblycarpa an excellent candidate parent for somatic fusion experiments. Isolation of leaf protoplasts from all three citranges and the sour orange + Flying Dragon somatic hybrid was routine, but was more difficult from Flying Dragon and Rubidoux trifoliate oranges which

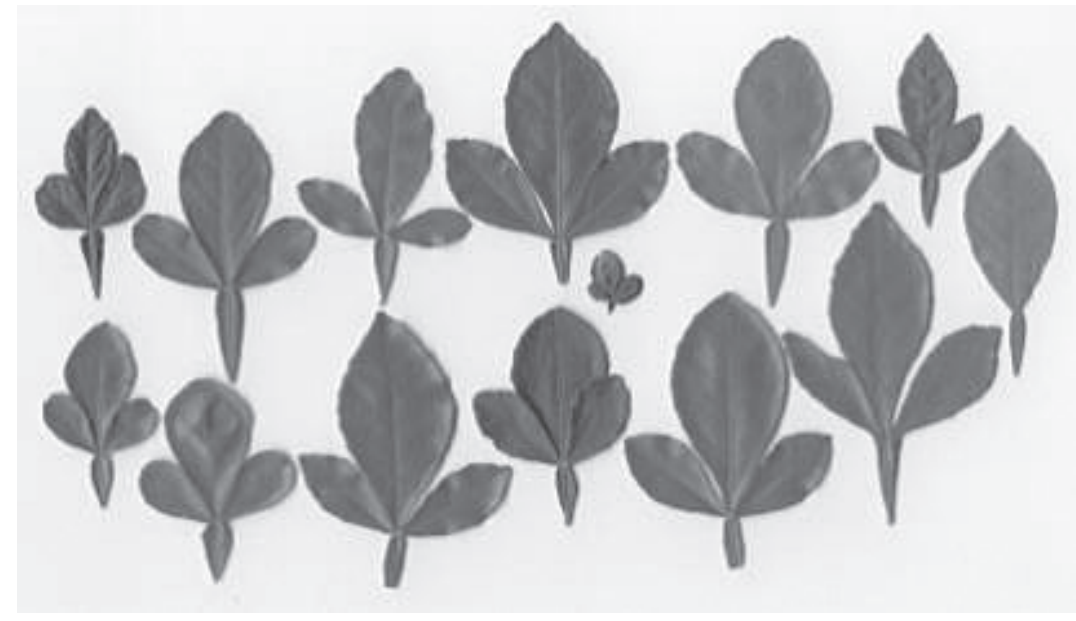

Fig. 1. Leaf morphology of the six citrus somatic hybrids. From left to right, upper row: Rubidoux, Carrizo, Benton, Sour orange + Flying Dragon, C-35, Flying Dragon; lower row: Amblycarpa + Rubidoux, Amblycarpa + Carrizo, Amblycarpa + Benton (4X), Amblycarpa + Benton (6X), Amblycarpa + (Sour orange + Flying Dragon) (smallest leaf in the center), Amblycarpa + C-35, Amblycarpa + Flying Dragon; unifoliate leaf on the right: Amblycarpa mandarin.

required the use of leaves from relatively new flushes grown under low-light conditions.

For most fusion cultures, plating efficiencies were so high that mats of embryogenic callus covered most plates. After 4 to 8 weeks on solid medium, green globular, torpedo, and heart-shaped somatic embryos were produced and transferred to the embryo enlargement medium. Embryoid formation and enlargement occurred rapidly for the three Amblycarpa + citrange combinations and from the Amblycarpa + Flying Dragon combination. Embryo recovery and growth rate from the other two combinations was less efficient, and therefore required additional time. For all combinations, large abnormal embryos cultured on DBA3 medium produced multiple shoots. Numerous plants were recovered from all six parental combinations and acclimated to greenhouse conditions as previously described (Grosser and Gmitter, 1990). Although the exact numbers of regenerated somatic hybrid plants for each combination were not recorded, we now have more than 50 plants from each tetraploid combination (combined regenerated plants and rooted cuttings) that have been entered into various rootstock evaluation schemes.

Leafmorphology and ploidy determination. Afew plants that expressed a diploid unifoliate leaf morphology very similar to that of Amblycarpa mandarin were recovered from each parental combination. These were probably plants that regenerated directly from unfused Amblycarpa protoplasts. Also, a few plants that expressed a diploid trifoliate leaf morphology very similar to that of the leaf parent were recovered from all parental combinations with the exception of the Amblycarpa + Flying Dragon and Rubidoux trifoliate oranges. Previous research has shown that in all cases studied, diploid plants that have the morphology of the leaf parent are cybrids that contain the nuclear genome of the leaf parent, and the mitochondrial genome of the callus or suspension parent (Cabasson et al., 2001; Grosser et al., 1996; Moreira et al., 2000b; Moriguchi et al., 1996). Therefore, these plants in the present study are putative cybrids. Embryogenic culture cells contain larger quantities of mitochondria than leaf cells, and it has been hypothesized that such higher quantities are required to provide the energy necessary for somatic embryogenesis, thus allowing plant regeneration (Moreira et al., 2000b).

From all parental combinations [except $\mathrm{Amb}+(\mathrm{SO}+\mathrm{FD}), 2 \mathrm{X}+4 \mathrm{X}$ fusion which should produce hexaploids], the most frequently observed leaf morphology was that of the tetraploid trifoliate type, intermediate to that of the parents (Fig. 1). These plants were subsequently confirmed as somatic hybrids by flow cytometry and RAPD analysis. The dominant trifoliate leaf character from Poncirus trifoliata has been used previously to facilitate verification of somatic hybrids (Grosser and Chandler, 2000; Grosser et al., 1998; Guo et al., 2002). A few plants from the Amblycarpa + C-35 combination had even thicker and rounder leaves than the putative tetraploid somatic hybrids, suggesting a higher ploidy level.

Flow cytometry analysis confirmed the suspected ploidy level of all regenerated plants. Plants with Amblycarpa morphology and the putative cybrid plants resembling their respective leaf parents were diploid. Putative somatic hybrids of Amblycarpa with the three citranges, Flying Dragon, and Rubidoux trifoliate orange were tetraploid, with the exception of the Amblycarpa + C-35 plants mentioned above, which were confirmed as hexaploids (Fig. 2). Although no hexaploid control was available, flow cytometry analyses showed that these plants produced peaks in a position indicating that the average size nuclei was about twice that of Persian lime, a known triploid. This is the second example of hexaploid plant recovery from diploid + diploid fusion, as intergeneric somatic hybrid plants of sweet orange + Clausena lansium (Lour.) Skeels, a sexually incompatible citrus relative, were reported previously by Guo and Deng (1999). 
Breeding, Cultivars, Rootstocks, \& Germplasm Resources

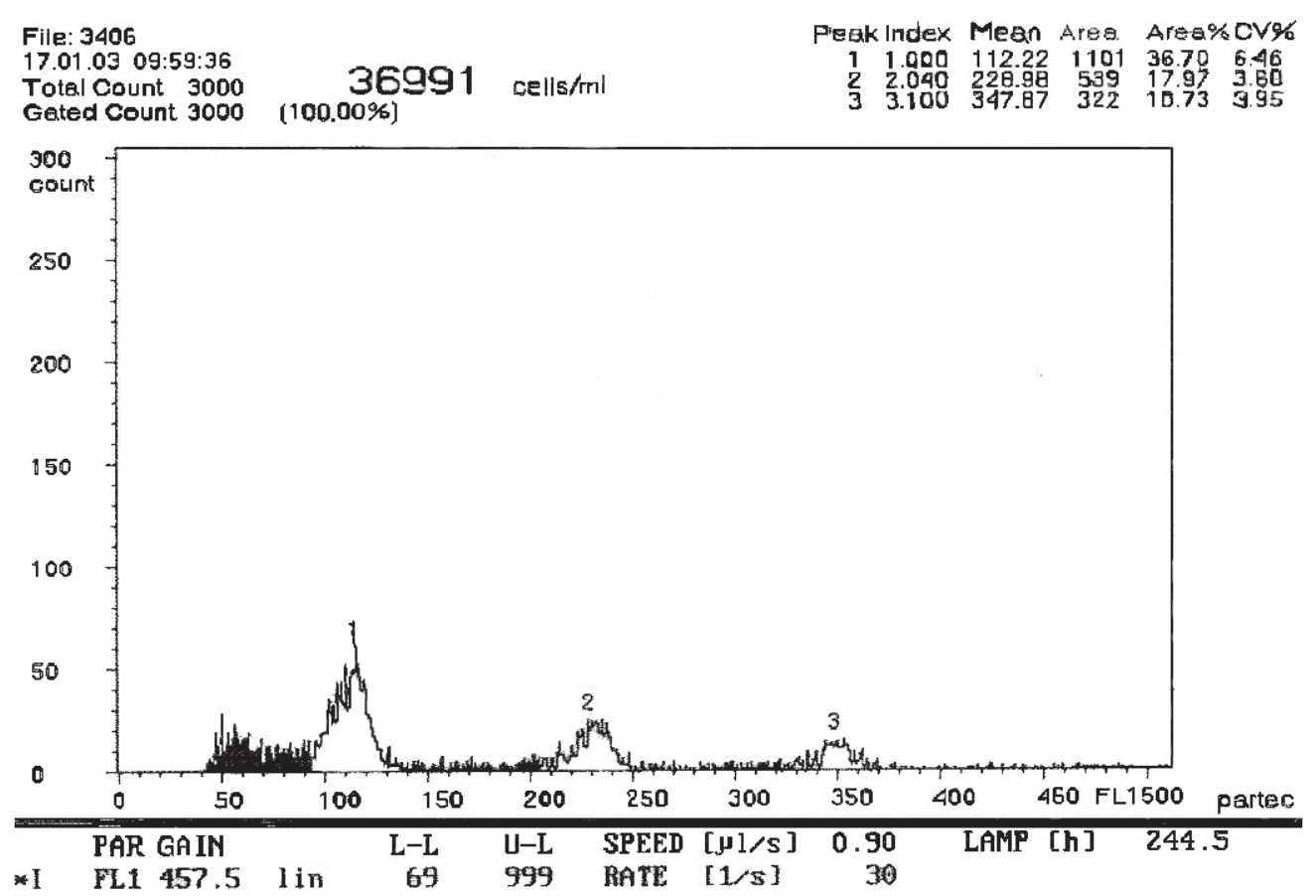

Fig. 2. Ploidy determination by flow cytometry analysis. Peak 1: diploid C-35 citrange; Peak 2: tetraploid Amblycarpa + C-35; Peak 3: hexaploid Amblycarpa $+\mathrm{C}-35$.

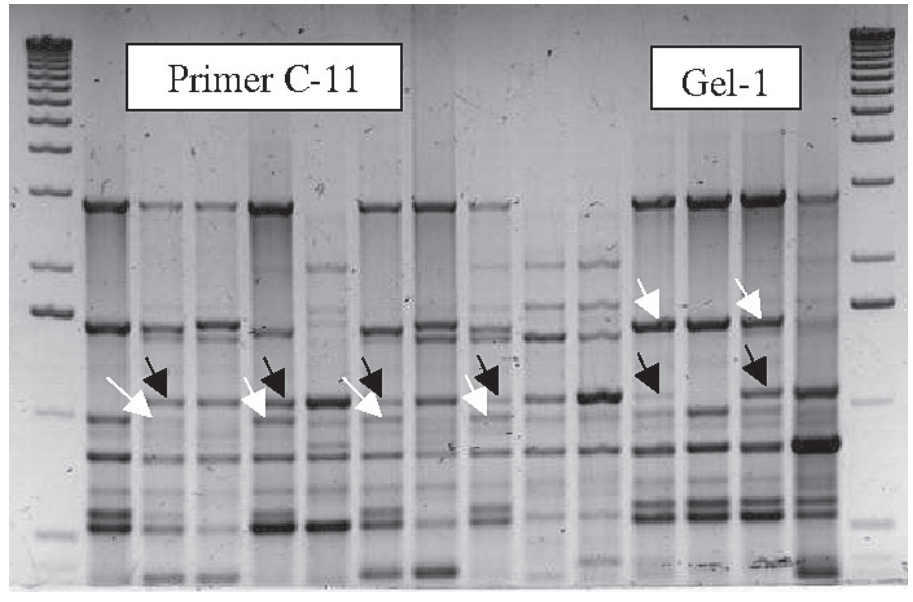

$\begin{array}{lllllllllllllll}1 & 2 & 3 & 4 & 5 & 6 & 7 & 8 & 9 & 10 & 11 & 12 & 13 & 14\end{array}$

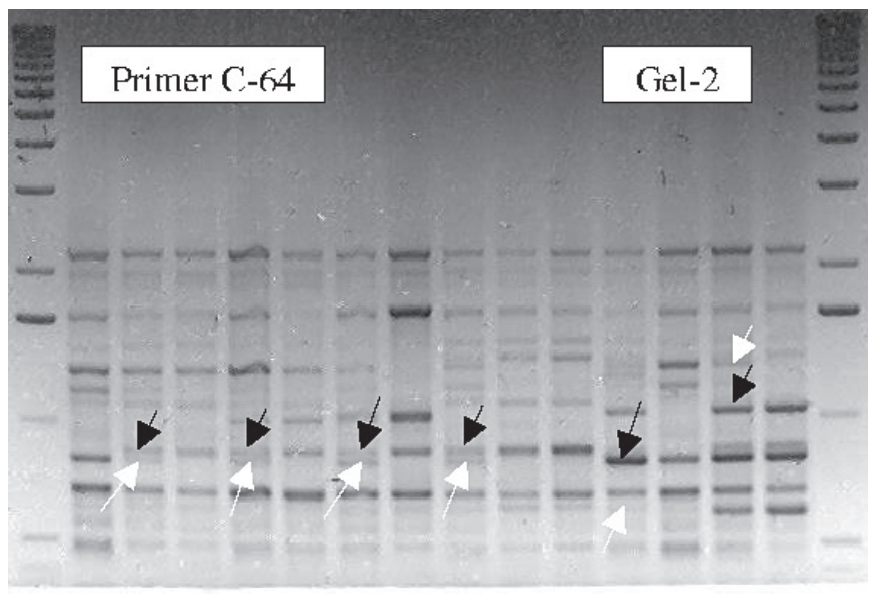

$\begin{array}{lllllllllllllll}1 & 2 & 3 & 4 & 5 & 6 & 7 & 8 & 9 & 10 & 11 & 12 & 13 & 14\end{array}$

Fig. 3. RAPD patterns of intergeneric somatic hybrids and their parental genotypes. First and last lanes-1 kb ladder. Gel-1 products amplified by operon primers C-11 and Gel-2 with C-64. Lane 1-Amblycarpa; 2-Amblycarpa + Carrizo citrange; 3-Carrizo citrange; 4-Amblycarpa + Benton citrange; 5-Benton citrange; 6-Amplycarpa + C-35 citrange; 7-C-35 citrange; 8-Amblycarpa + Rubidoux; 9-Rubidoux; 10-Flying Dragon; 11-Amblycarpa + Flying Dragon; 12-Amblycarpa; 13-Amblycarpa + (Sour orange + Flying Dragon); 14-Sour orange + Flying Dragon (SOFD). White arrows show complimentary bands from Amblycarpa and black arrows from the corresponding leaf parent in the hybrid profiles.

Interestingly, they recovered no tetraploid somatic hybrids of this combination. Putative somatic hybrid plants from the fusion of Amblycarpa with the teteraploid sour orange + Flying Dragon somatic hybrids were also hexaploid, as expected.

RAPD analysis. RAPD analysis using leaf total genomic DNA of the putative somatic hybrids and their parents were displayed through gel electrophoresis and showed that the suspected somatic hybrid plants from all six parental combinations exhibited banding patterns complementary to those of the respective parents, using both $\mathrm{C}-11$ and $\mathrm{C}-64$ primers (Fig. 3). This demonstrates a nuclear contribution from both parents in each of the six new somatic hybrids.

CAPS. Three mt-specific and four cp-specific primer pairs were used to determine cytoplasmic genome inheritance. PCR products from the six putative somatic hybrids and corresponding parents were digested with TaqI, and as expected, all six somatic hybrids contain only Amblycarpa mtDNA (Fig. 4). This agrees with previous reports showing that somatic hybrids produced from the fusion of embryogenic callus/suspension culture protoplasts with leaf protoplasts always contain exclusively the mtDNA of the callus/suspension parent (Grosser et al., 2000;
Guo et al., 2002; Moreira et al., 2000a). For cpDNA analysis, PCR products using primer pairs rbcL-PSAI, and TrnD-TrnT and cut with TaqI showed polymorphisms, and the cpDNA of four somatic hybrids (FD + Amb, Benton + Amb, SOFD + Amb, C-35 + Amb) was from Amplycarpa, and the remaining two (Carrizo + Amb, Rub + Amb) was from their corresponding leaf parent (Fig. 5). Although only one plant of each fusion combination was analyzed for cp-DNA inheritance, it is well known that cpDNA is randomly inherited in various citrus somatic hybrids (Grosser et al., 2000; Guo and Deng, 2001). CAPS analysis of somatic hybrids in higher plants using 


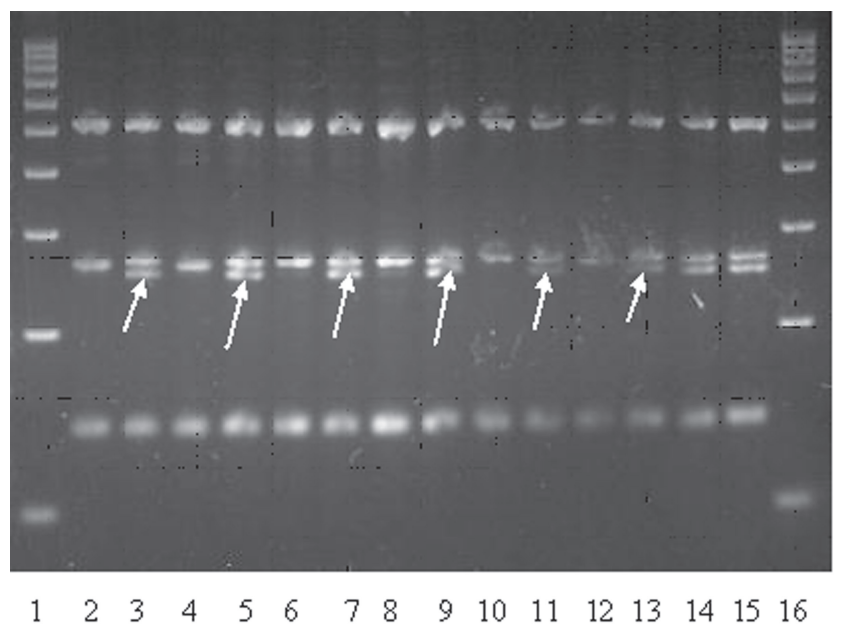

Fig. 4. Mitochondrial DNA analysis of the six somatic hybrids. MtDNA banding pattern amplified using the primer pair 18S rRNA-5S rRNA, and digested with TaqI. Lane 1-1 kb ladder; 2-Flying Dragon; 3-Amblycarpa + Flying Dragon; 4-Benton citrange; 5-Amblycarpa + Benton citrange; 6-Sour orange + Flying Dragon (SOFD); 7-Amblycarpa + (Sour orange + Flying Dragon); 8-C-35 citrange; 9-Amblycarpa + C-35 citrange; 10-Carrizo citrange; 11-Amblycarpa + Carrizo citrange; 12-Rubidoux ; 13 -Amblycarpa + Rubidoux ; 14, 15-Amblycarpa; 16-1 kb ladder. Characteristic bands of the hybrids were identical to those of the Amblycarpa embryogenic suspension parent, as indicated by the white arrows.

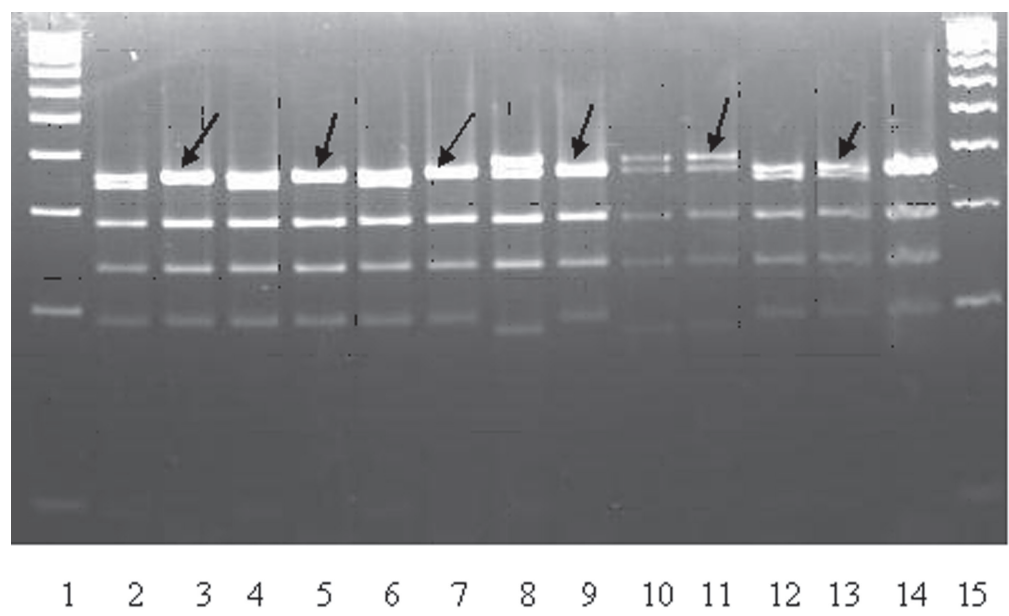

Fig. 5. Chloroplast DNA analysis of the six somatic hybrids. CpDNA banding pattern amplified using the primer pair: TrnD-TrnT, and digested with TaqI. Lane 1-100 bp ladder; 2-Flying Dragon; 3-Amblycarpa + Flying Dragon; 4-Benton citrange; 5-Amblycarpa + Benton citrange; 6-Sour orange + Flying Dragon (SOFD); 7-Amblycarpa + (Sour orange + Flying Dragon); 8-C-35 citrange; 9-Amblycarpa + C-35 citrange; 10-Carrizo citrange; 11-Amblycarpa + Carrizo citrange; 12-Rubidoux ; 13-Amblycarpa + Rubidoux ; 14-Amblycarpa; 15-100 bp ladder. Characteristic bands of the hybrids were identical to those of the Amblycarpa embryogenic suspension (lanes 3, 5, 7, and 9); lanes 11 and 13 identical to those of the leaf parents (showed by arrows)

mitochondrial or chloroplast specific primer pairs has been applied recently, where it was proved to be an efficient, simple, and reliable method for cytoplasmic genome characterization (Bastia et al., 2001; Cheng et al., 2003; Guo et al., 2002).

\section{Concluding Remarks}

Sets of somatic hybrid plants were produced from six new parental combinations, combining Amblycarpa mandarin with six different trifoliate/trifoliate hybrid selections, in efforts to combine the complementary horticultural and disease resistance attributes of the parents. Amblycarpa mandarin as a parent. Amblycarpa mandarin appears to be more widely adapted and is more vigorous than Cleopatra, Changsha, and Sunki mandarins as a rootstock. Mexican lime produces better yields and fruit size on Amblycarpa than Shekwasha, Changsha, and Sun Chu Sha mandarins (Medina-Urrutia, 1996; Medina-Urrutia and Robles-Gonzalez, 2000b). The leaf parents Benton, Carrizo, and C-35 citranges; Rubidoux and Flying Dragon trifoliate oranges; and the sour orange + Flying Dragon somatic hybrid used in this study cover a wide range of tree vigor. Production of tree-size controlling rootstocks is a goal of this research, as the best-performing rootstocks for Mexican lime, at present, generally produce unacceptably large trees that are more expensive to harvest. All of the somatic hybrid rootstock candidates reported herein are expected to produce small- to mediumsize trees. The two hexaploid combinations Amblycarpa + C-35, and Amblycarpa + (sour orange + Flying Dragon) could produce very dwarfed trees that may have potential for potted ornamental citrus production. The trifoliate/trifoliate hybrid leaf parents used in this study were also selected on the basis of their ability to produce high yields of high-quality fruit, and for their resistance to citrus tristeza virus and Phytophthora nicotianae. All of the new somatic hybrids reported herein have been propagated either by tissue culture and/or rooted cuttings for further evaluation as potential rootstocks for limes and other citrus. Citrus rootstock improvement is a long-term venture, and new rootstock hybrids must be evaluated in replicated commercial field trials conducted on several soil types over several years to determine their value.

\section{Literature Cited}

Bastia, T., N. Scotti, and T. Cardi. 2001. Organelle DNA analysis of Solanum and Brassica somatic hybrids by PCR with universal primers. Theor. Appl. Genet. 102:1265-1272.

Bowman, K.D. 2000. New hybrid citrus developed by U.S. Department of Agriculture. Proc. Intl. Soc. Citricult. IX Congr. 1:51.

Bronson, C., R. Gaskalla, and M. Kesinger. 2002. Annual report (1 July 2002-30 June) of the Bureau of Citrus Budwood Registration. Florida Dept. Agr. and Consumer Serv., Div. of Plant Ind., Winter Haven.

Cabasson, C.M., F. Luro, P. Ollitrault, and J.W. Grosser. 2001. Non-random inheritance of mitochondrial genomes in citrus hybrids produced by protoplast fusion. Plant Cell Rpt. 20:604-609.

Castle, W.S. 1987. Citrus rootstocks, p. 361-399. In: R.C. Rom. and R.F. Carlson (eds.). Rootstocks for fruit crops. Wiley, New York.

Castle, W.S., D.P.H. Tucker, A.H. Krezdorn, and C.O. Youtsey. 1993. Rootstocks for Florida citrus, 2nd ed., p. 1-92. Univ. of Florida, IFAS, Gainesville.

Cheng, Y.J., W.W. Guo, and X.X. Deng. 2003. Molecular characterization of cytoplasmic and nuclear genomes in phenotypically abnormal Valencia orange (Citrus sinensis) + Meiwa kumquat (Fortunella crassifolia) intergeneric somatic hybrids. Plant Cell Rpt. 21:445-451.

Deng, X.X., J.W. Grosser, and F.G. Gmitter, Jr 1992. Intergeneric somatic hybrids plants from fusion of Fortunella crassifolia cultivar 'Meiwa' with Citrus sinensis cultivar 'Valencia'. Scientia Hort. 49:55-62.
Ferguson, J.J. and S.M. Garnsey. 1993. Citrus virus and viruses-like diseases. Univ. of Florida, Florida Coop. Ext. Serv. Circ. 1131.

Forner, J.B., M.A. Forner, A. Alcaide, S. VerdejoLucas, and F.J. Sorribas. 2000. New hybrid citrus rootstocks in Spain. Proc. Intl. Soc. Citricult. IX Congr. 1:58-61.

Foguet, J.L. 2000. New rootstocks for Argentina industry. Proc. Intl. Soc. Citricult. IX Congr. 1:56-57.

Grosser, J.W. 2003. Somatic hybridization in citrusA relevant technique for variety improvement in 21st century. Acta Hort. 622:491-497.

Grosser, J.W. and J.L. Chandler. 2000. Somatic hy- 


\section{Breeding, Cultivars, Rootstocks, \& Germplasm Resources}

bridization of high yield, cold hardy and disease resistant parents for citrus rootstock improvement. J. Hort. Sci. Biotechnol. 75(6):641-644.

Grosser, J.W. and F.G. Gmitter, Jr. 1990. Protoplast fusion and citrus improvement. Plant Breeding Rev. 8:339-374.

Grosser, J.W., F.G. Gmitter, Jr., F. Sesto, X.X. Deng, and J.L. Chandler. 1992. Six new somatic Citrus hybrids and their potential for cultivar improvement. J. Amer. Hort. Sci. 117:169-173.

Grosser, J.W., F.G. Gmitter, Jr., N. Tusa, G.R. Recupero, and P. Cucinotta. 1996. Further evidence of a cybridization requirement for plant regeneration from citrus leaf protoplasts following somatic fusion. Plant Cell Rpt. 15:672-676.

Grosser, J.W., J. Jiang, E.S. Louzada, J.L. Chandler, and F.G. Gmitter, Jr. 1998. Somatic hybridization an integral component of citrus cultivar improvement: II. Rootstock improvement. HortScience 33:1060-1061.

Grosser, J.W., E.S. Louzada, F.G. Gmitter, Jr., and J.L. Chandler. 1994. Somatic hybridization of complimentary Citrus rootstocks: Five new hybrids. HortScience 29:812-813.

Grosser, J.W., P. Ollitrault, and O. Olivares-Fuster. 2000. Somatic hybridization in citrus: an effective tool to facilitate variety improvement. In Vitro Cell Dev. Biol. Plant. 36:434-449.

Guo, W.W. and X.X. Deng. 1999. Intertribal hexaploid somatic hybrid plant regeneration from electrofusion between diploids of Citrus sinensis and its sexually incompatible relative, Clausena lansium. Theor. Appl. Genet. 98:581-585.

Guo, W.W. and X.X. Deng. 2001. Wide somatic hybrids of Citrus with its related genera and their potential in genetic improvement. Euphytica 118:175-183.

Guo, W.W., Y.J. Cheng, and X.X. Deng. 2002. Regeneration and molecular characterization of intergeneric somatic hybrids between Citrus reticulata and Poncirus trifoliata. Plant Cell Rpt. 20:829-834.

Guo, W.W., C.H. Zhou, H.L. Yi, and X.X. Deng. 2000. Intergeneric somatic hybrid plants between Citrus and Poncirus trifoliata and evaluation of their root rot resistance. Acta Botanica Sinica 42:668-672.

Medina-Urrutia, V.M. 1996. Comportamiento de portainjertos de limón mexicano en Colima. INIFAP-CIRPAC-Campo Experimental Tecoman. Folleto Tecnico \# 3.

Medina-Urrutia, V.M. and M.M. Robles-Gonzalez. 2000a. Mexican lime agro-industry: An overview. Proc. Intl. Soc. Citricult. IX Congr. 1:515-519.

Medina-Urrutia, V.M. and M.M. Robles-Gonzalez. 2000b. Potential of trifoliate rootstocks for Mexican lime trees. Proc. Intl. Soc. Citricult. IX Congr. 1:490-493.

Miller, J.E., J.G.J. Maritz, I.J. Froneman, and J. Koekemoer. Potential citrus cultivars in South Africa's scion and rootstock development pipeline. Proc. Intl. Soc. Citricult. IX Congr. 1:62-65.

Moreira, C.D., C.D. Chase, F.G. Gmitter, Jr., and J.W. Grosser. 2000a. Transmission of organelle genomes in citrus somatic hybrids. Plant Cell Tissue Organ Cult. 61:165-168.

Moreira, C.D., C.D. Chase, F.G. Gmitter, Jr., and J.W. Grosser. 2000b. Inheritance of organelle genomes in citrus somatic cybrids. Mol. Breeding 6:401-405.

Moriguchi, T., T. Hidaka, and M. Omura. 1996. Genotype and parental combination influence efficiency of cybrid induction in citrus by electrofusion. HortScience 31:275-278.

Ohgawara, T., H. Uchimiya, S. Ishii, and S. Kobayashi. 1994. Somatic hybridization between Citrus sinensis and Poncirus trifoliata. Vol. 27, p. 339-453. In: Y.P.S. Bajaj (ed.). Biotechnol. Agr. For. Springer-Verlag, Berlin Heidelberg.

Ollitrault, P., D. Dambier, F. Luro, and C. Duperray. 1994. Nuclear genome size variations in Citrus. Fruits 49:390-393.

Ollitrault, P., D. Dambier, Sudahono, and F. Luro. 1996. Somatic hybridization in Citrus: Some new hybrids and alloplasmic plants. Proc. Intl. Soc. Citricult. 2:907-912.

Valdez-Veduzco, J. and V.M. Medina-Urrutia. 1981. Influence of rootstocks on Mexican lime performance in Colima, Mexico. Proc. Intl. Soc. Citricult. 1:142-144. 